\title{
THE $o$-GRADE OF THE INDO-EUROPEAN ABLAUT IN THE LIGHT OF NATURALNESS
}

If the (probably obsolescent) point of view is accepted that the o-grade of the Proto-Indo-European ablaut arose from the more basic e-grade under lack of word accent, Naturalness Theory can state the assumptions which make it possible to predict the distribution of the two grades in dependence upon the accent. One assumption is, >nat (+accented, - accented) / vowel, the other assumption is, $>$ nat (e-vowel, o-vowel). Using "markedness agreement", the consequence is as follows. If there is any difference between the e-vowel and the o-vowel, such that one kind of vowel is accented, and the other kind of vowel is unaccented, it is the e-vowel that tends to be accented, and it is the o-vowel that tends to be unaccented.

This method can be used to check if some presupposed language state is really possible in natural languages.

This paper discusses an aspect of the old (probably obsolescent) text-book wisdom concerning the Indo-European ablaut, namely the (once generally accepted) assumption that the $o$-grade is younger than than the e-grade: the o-grade arose from the $e$ grade whenever the latter was not accented (under certain additional conditions). The aim of this paper is to show that accented $e$-grade and unaccented $o$-grade constitute a possible state of affairs in natural languages. To this purpose, I will make use of Naturalness Theory as currently practised especially in Austrian linguistics (see Dressler 2000), and in my own surroundings at the University of Ljubljana (cf. Orešnik 2001). Naturalness Theory operates with naturalness scales which ascribe greater or smaller naturalness to language units and categories. One of the leading theoreticians in the field of natural morphology, Austrian-based Willi Mayerthaler, distinguishes two kinds of naturalness, sem- and sym-naturalness (cf. Mayerthaler 1981 etc.). Since I will make use of sem-naturalness only in the present paper, and as the latter is very similar to traditional markedness, I will refrain from discussing the difference between sem- and sym-naturalness. I will use the bare term naturalness, and set up the following approximate equations: more natural $=$ less marked, less natural $=$ more marked . The predicate natural will be abbreviated as 'nat' in scales.

The essential difference between markedness and naturalness lies in the way they are determined. Markedness is determined (computed) using the means at the disposal within the language whose units/categories are being dealt with. For instance, it can be assumed that unit A is less marked than unit B, if unit A's sphere of usage is greater that unit B's sphere of usage. Other ways of ascertaining markedness are comfortably enumerated e.g. in Andersen 2001. Contrariwise, the determination of naturalness is not limited to the means at the disposal in a single language, and broader data, for 
example typological data, are made extensive use of. For instance, if category A is wider-spread cross-linguistically than category $B$, it can be assumed that category $A$ is more natural than category $\mathrm{B}$. Thus naturalness allows more ways of computation than markedness. Therefore I will make use of naturalness in the present paper.

The principled difference between markedness and naturalness is only apparently great. In both instances, the essential act is to determine indirectly how the human brain evaluates the relative difficulty, the relative stability etc. of any units and categories of a language.

For the purposes of the present paper I propose to suggest two new naturalness scales. One is, >nat (+accented, -accented) / vowel. The other scale is, >nat (e-vowel, $o$-vowel). I proceed to adduce argumentation in support of the two scales.

The scale, >nat (+accented, -accented) / vowel asserts that an accented vowel is more natural than an unaccented vowel. The term accent is here used neutrally with respect to the kind of accent; the latter can be dynamic or tonemic. The scale can be supported with typological facts. In some languages, the word is only or almost only monosyllabic. Vietnamese is one of such languages. It distinguishes accented and unaccented words. The class of unaccented words is limited, the class of accented words is not limited. Obviously, accented words are basic in this language (and in fact in any language). It follows that the accented monosyllabic word is prototypical in natural languages. Given that in languages whose words are monosyllabic any difference between an accented word and an accented vowel can be neglected, it can be asserted that the accented vowel is the prototypical vowel in the languages of the world. This jibes well with the known fact that the class of accented vowels of many languages is richer than the class of unaccented vowels. It has been observed within the theory of markedness that what is less marked often displays richer forms than what is more marked. For instance, it is expected that, in a language having case forms, the singular of nominal parts of speech shows more cases than the non-singular of those parts of speech.

The suggestion that monosyllabic accented words are prototypical can be supported in a negative way as well. There are no languages displaying only one structural type of accented words such that that structural type would not be monosyllabic.

My other scale is, $>$ nat ( $e$-vowel, $o$-vowel), i.e. an $e$-vowel is more natural than an $o$-vowel. This scale can also be supported with typological data. As emphasized by Roman Jakobson 60 years ago (Jakobson [1940] 1969, 75-6 with references), some languages have $e$-vowels and lack $o$-vowels; on the other hand, there are no languages having $o$-vowels and lacking $e$-vowels. Jakobson also drew attention to the following: during language acquisition, the child acquires $e$-vowels earlier than $o$-vowels.

I now propose to link the two scale with each other. I will use the principle of "markedness agreement" as formulated by Andersen 1972. (To be sure, Andersen refers to the work of the Slavic scholar František Mareš. However, it is a fact that "markedness agreement" became known internationally because of Andersen and in his interpretation and formulation.) Andersen's principle has remained uncontested; 
Andersen 2001 repeats it and adds new exemplification. According to "markedness agreement", an instance of less marked tends to associate with another instance of less marked, and an instance of more marked tends to associate with another instance of more marked. Transferred to naturalness, this means: an instance of more natural tends to associate with another instance of more natural, and an instance of less natural tends to associate with another instance of less natural.

The principle dictates that the accented vowel is linked with $e$-vowel, and that the unaccented vowel is linked with $o$-vowel.

However, since the link between the accented vowel and the $e$-vowels and the link between the unaccented vowel and the $o$-vowels are not the only possible links within the two pairs, other links being conceivable (for instance, between the vowel colour and the phonetic environment of the vowel), the preceding paragraph entitles me to suggest only the following two cautious alternative formulations (a) and (b) (whose format has been taken from Janez Orešnik's work, see Orešnik 2001 passim):

(a) If there is any difference between the accented and the unaccented vowel, such that one vowel is an $e$-vowel, and the other vowel is an $o$-vowel, then it is the accented vowel that tends to be an $e$-vowel, and it is the unaccented vowel that tends to be an $o$-vowel.

(b) If there is any difference between an $e$ - and an $o$-vowel, such that one of them is accented, and the other is unaccented, then it is the $e$-vowel that tends to be accented, and it is the $o$-vowel that tends to be unaccented.

I suggest that it can be seen from $(a-b)$ that the link between the accented vowel and the $e$-vowel as well as the link between the unaccented vowel and the $o$-vowel are natural in the sense that one would not be astonished if a language were found displaying exactly such a configuration of accentedness and vowel colour. In part, such a configuration can be observed (indirectly through reflexes or even directly) in some old Indo-European languages.

It is known that comparative linguists reconstructing prehistorical states often address the question as to whether the reconstructed state is a possible state in natural languages. If they succeed in finding some natural language in which the analogue of the reconstructed state is realized, the answer to the question is positive. However, it the linguist fails to find such a natural language, the question arises as to how to support any assertion that the reconstructed state is a possible state in natural languages. I suggest that the linguist could, at least in some cases, profit from the method described above.

To avoid misunderstandings, let me repeat that the above method helps to describe a reconstructed prehistorical state as a POSSIBLE state in natural languages. The method does NOT assert that some given reconstructed prehistorical state is true/correct. Consequently my paper should not be construed as advocating certain aspects of some (obsolescent?) theory concerning the Indo-European ablaut. 


\section{References}

ANDERSEN, Henning, 1972. "Diphthongization", Language 48, 11-50.

ANDERSEN. Henning, 2001. "Markedness and the theory of linguistic change". In press.

Bool., Geert, Christian LeHMANN and Joachim Mugdan (eds.), 2000. Morphologie: ein internationales Handbuch zur Flexion und Wortbildung. Volume I. Berlin, de Gruyter.

DRESSLER, Wolfgang U., 2000. "Naturalness". In: Booij et al. eds, 288-96.

JAKOBSON, Roman, [1940] 1969. Kindersprache, Aphasie und allgemeine Lautgesetze. Frankfurt/M, Suhrkamp. MAYERTHALER, Willi, 1981. Morphologische Natürlichkeit. Wiesbaden, Athenaion.

OREŠNIK, Janez, 2001. A predictable aspect of (morpho) syntactic variants. Ljubljana, Slovenska akademija znanosti in umetnosti.

\section{Povzetek}

\section{OJEVSKA STOPNJA PRAINDOEVROPSKEGA PREVOJA V LUČI JEZIKOVNE NARAVNOSTI}

Če se postavimo na nekdaj splošno sprejeto (a danes verjetno zastarelo) stališče, da je tisti praindoevropski ojevski vokalizem, ki je v okviru preglasa nastal iz osnovnejšega ejevskega vokalizma, rezultat naglasnih razmer $\mathrm{v}$ besedi, namreč da je o nastal iz e-ja, kadar slednji ni bil naglašen, se dajo $\mathrm{v}$ okviru teorije o jezikovni naravnosti izreči predpostavke, na podlagi katerih se napoveduje razvrstitev ejevskega in ojevskega vokalizma glede na naglas. Ena predpostavka je >nat ( + naglašen, -naglašen)/samoglasnik. Druga predpostavka je >nat (ejevski, ojevski)/vokalizem. Zdaj po "ujemanju zaznamovanosti" sledi: če je kak razloček med ejevskim in ojevskim vokalizmom, tako da je ena vrsta vokalizma naglašena in druga vrsta vokalizma nenaglašena, potem teži k naglašenosti ejevski vokalizem in $\mathrm{k}$ nenaglašenosti teži ojevski vokalizem.

Na ta način se da preverjati, ali so neke predpostavljene jezikovne razmere $v$ naravnih jezikih tudi res možne. 